\title{
A Qualitative Investigation on Work in NGOs: The Case of Songkhla Province of Thailand
}

\author{
Phathara-on Wesarat (Corresponding author) \\ Dept. of Social Sciences, Faculty of Humanities and Social Sciences, Prince of Songkla \\ University, Pattani Campus \\ 181, Chareonpradit Rd., Rusamilae, Pattani 94000, Thailand \\ Tel: 0066-7333-1304Ｅ-mail: phatharaon-w@ bunga.pn.psu.ac.th \\ Mohmad Yazam Sharif \\ School of Business Management, College of Business, Universiti Utara Malaysia \\ 06010, UUM Sintok, Kedah Darul Aman, Malaysia \\ Tel: 6-04-928-5055Ｅ-mail: yazam@uum.edu.my \\ Abdul Halim Abdul Majid \\ School of Business Management, College of Business, Universiti Utara Malaysia \\ 06010, UUM Sintok, Kedah Darul Aman, Malaysia \\ Tel: 6-04-928-3787Ｅ-mail: ahalim@uum.edu.my
}

Accepted: June 02, 2013 Published: July 12, 2013

Doi:10.5296/ijhrs.v3i2.3873 URL: http://dx.doi.org/10.5296/ijhrs.v3i2.3873

\begin{abstract}
The concept of work in Non-Governmental Organizations (NGOs) specifically in Songkhla province of Thailand is highlighted in this paper. The study assumed that the meaning of work in NGOs is different from other types of organizations such as business and governmental organizations. NGO operations are seen to be different in terms of their goals when compared to those organizations. Even though research on work had been widely conducted in the business as well as the governmental sectors worldwide, few studies on this issue had been done in the NGO or non-profit sector. The concept of work in NGOs needs to
\end{abstract}


be explored further in order for interested parties to get a true understanding of the nature of work in NGO sector. The research questions posed in this paper relate to how and why the work in NGOs influences the NGO professionals. The objective of this paper is to present some findings based on an in-depth study on the meaning of work in NGOs. This study consists of two core aspects of work: subjective and objective aspects. The respondents in this paper were 16 professionals (i.e. university graduates) selected from five local NGOs in Songkhla province of Thailand. This study used a mixed method within qualitative approach comprising in-depth interviews, non-participant observation, and secondary documents. This study showed that the NGO professionals had given high values on the subjective aspects of work because they were seeking fulfillment from work, while the objective aspects of work were seen to be less important to them.

Keywords: Work, Non-Governmental Organizations, Objective Aspect, Subjective Aspect

\section{Introduction}

Work is one of the important aspects of life for most people around the world (Helyer, 2011; Porter, 2004; Selmer \& Littrell, 2010; Snir \& Harpaz, 2012). Work is defined as a purposeful activity that is pursued in exchange for money or other rewards and it makes something useful (Woodside, Melinda, Devison, Hannon \& Sweeney, 2012). Work is done to attain the goals both organizational goals and personal goals (Mansfield, Wosnitza \& Beltman, 2012). As in any organization, NGOs need to achieve particular goals (Mihr, Philips \& Duyvesteyn, 2011). Therefore, the study of work in NGOs benefits NGO managers to get the notion of work that could be applied to their organizational management.

The previous scholars viewed work from diverse perspectives such as economics, politics, sociology, and management (Caplow, 1964; Grint, 2005). Work plays important roles in life, since it can be considered "as the primary source of income, and as a base for social participation, social status, consumption, health, family life, and so on" (Selmer \& Littrell, 2010, p. 33). In this paper, however, the researchers presented the work from human resource management (HRM) perspective. The issues of HRM in NGOs have received less attention by the researchers in the past. Most studies of NGOs focused on the roles of NGOs rather than their HRM activities (Brown, Ebrahim \& Batliwala, 2012; Ibrahim \& Aziz, 2012; Leonard, 2002).

NGOs are the organizations that are not part of the government and their goals are not for profit making (Jepson, 2005; Stiles, 2002). The three terms: third sector, non-governmental organizations (NGOs), and non-profit organizations (NPOs) are used synonymously (Reichel \& Rudnicka, 2009). The two studies by Benz (2005) and Tortia (2008) maintain that employees who work for NPOs are more satisfied with their jobs compared to those people who work in firms. It can be assumed that NPOs are better for motivating employees especially with the job itself (Pennerstorfer \& Schneider, 2010). NPOs or NGOs could not offer incentive compensation to employees because of the limited funding and the financial dependence on donors (Harsh, Mbatia \& Shrum, 2010). But they might offer attractive job 
characteristics to employees who prefer NGO jobs.

This paper presents the work in NGOs, both objective and subjective aspects and the influence of work on NGO professionals. It begins with literature review. It is then followed by methodology, findings and discussion, and conclusions respectively.

\section{Literature Review}

Work has two aspects, objective and subjective aspects (Maglio, Injoque-Ricle \& Leibovich de Figueroa, 2010; Vinopal, 2012). Objective aspect of work can be seen or observed directly such as work conditions (Maglio et al., 2010). Subjective aspect of work is related to how employee perceives his or her work such as satisfaction with work (Ljungberg \& Neely, 2007; Maglio et al., 2010; Vinopal, 2012). Work fulfills the needs of individual both economic and non-economic needs (Cartwright \& Holmes, 2006; Rosso, Dekas \& Wrzesniewski, 2010; Vaiman, Lemmergaard \& Azevedo, 2011). Some kinds of individual's needs are related to money (e.g. sustaining a standard of living and status), whereas some kinds of individual's needs are not related to money (e.g. skill development, self-esteem, psychological fulfillment, identity, and social interaction) (Coetzee \& Bergh, 2009).

From organizational perspective, work is important to both employees and employers since both of them expect to receive interest of work (Brown, Charlwood, Forde \& Spencer, 2007; Cartwright \& Holmes, 2006). Employers may offer compensation, job security, training, and promotion to employees in exchange for employees' responsibility, loyalty, and commitment (Cartwright \& Holmes, 2006; Conway \& Briner, 2002). It can be said that work provides either monetary exchange or non-monetary exchange for individual (Fock, Frederick \& Rodriguez, 2010; Medcof \& Rumpel, 2007).

In NGO sector, the research on work was rarely seen (Mitra, 2011). Work in NGOs might different from those business and governmental organizations, as they have different missions (Analoui \& Samour, 2012; Valentinov, 2012). Business organizations need to maximize profits for themselves (Baloh, Jha \& Awazu, 2008; Das \& Sengupta, 2010), while NGOs are described as non-profit-making organizations (Gray, Bebbington \& Collison, 2006). Governmental organizations aim to provide services to all citizens (Reddick \& Turner, 2012). In developing countries however, public services are inadequate (Deininger \& Mpuga, 2005) because of the lack of budget (Ananth, Prashanthini \& Visvanathan, 2010) and ineffective management (Bhuiyan, 2010). NGOs often serve disadvantaged people, particularly poor people or vulnerable people who are unable to gain access to the public services provided by governmental organizations (Brass, 2012; Burger \& Owens, 2010). Therefore, people who choose to work for NGOs have ideological goals such as helping others, being self-fulfilled, and improving the community (Bjerneld, Lindmark, McSpadden \& Garrett, 2006).

As NGOs lack financial rewards (Kamery, 2004; Rahman \& Sultana, 2012), the amount of remuneration seems to be less important to NGO workers (Bunchapattanasakul, Wiriyakosol \& Ya-anan, 2012; Mitra, 2011). NGO workers can be divided into two types: paid staff and unpaid staff (also referred to as voluntary staff) (Desai, 2003; Mitra, 2011; Owczarzak, 2010). However, NGO workers may be unable to work without sufficient financial rewards 
(Bjerneld et al., 2006). A study by Bjerneld et al. (2006) states that the volunteers were interested in job itself (e.g. an exciting challenge of job), while they also sought for secure working conditions and sufficient salary. Hence, objective and subjective aspects of work in NGOs are interesting issues for discussion. The influence of work on NGO professionals is highlighted in this paper.

\section{Methodology}

This study had adopted a mixed method within qualitative approach comprising in-depth interviews, non-participant observation, and secondary documents. In this paper, a mixed method refers to the use of multiple methodological techniques within qualitative approach (Berg, 2001). It can be used to investigate the same phenomenon in order to obtain more important aspects of reality (Berg, 2001). The research protocol was developed by the researcher and it was used as a guideline for the interview. Non-participant observation was based on the use of several materials such as research diary, taped cassettes, transcripts of the interviews, and photographs. The study also gathered secondary data from books, directory, journals, and past theses.

This study used purposive sampling which was considered as a suitable sampling technique for the participant selection. The listing of local NGOs in Songkhla province of Thailand was provided by a coordinator for NGO Coordinating Committee on Rural Development in the South of Thailand (NGO-COD South). Five NGOs were selected for this study as follows: 1) The Promotion of Quality of Work Life for Informal Sector (Production Scheme), 2) Consumer Right Protection Project, 3) Southern Alternative Agriculture Network, 4) Thai Sea Watch Association, and 5) Public Policy Effects Network. All five NGOs were the members of NGO-COD South.

Since the list of NGO professionals was unavailable, the researcher developed a current list of NGO professionals with the help of five NGO professionals who can give the specific information about the other professionals. Overall, 16 professionals were the participants in this study. The participant selection is based on the three criteria: 1) the manager or staff in the NGO was a university graduate, 2) the manager or staff in the NGO was willing to be interviewed, and 3) the NGO was willing to allow the researcher to observe their activities as a non-participant observer.

For qualitative data analysis, this study used Hahn's (2008) data analysis model which emphasizes category development using Microsoft Word and Microsoft Excel. Generally, the qualitative data analysis approaches aim to organize the data to become manageable for the researcher to analyze the data (Hahn, 2008; Miles \& Huberman, 1994). Since the decision to use manual or electronic methods depends on the size of participants (Basit, 2003), this study used manual method because it had a small size of participants.

\section{Findings and Discussion}

All 16 respondents were Thais. Nine of the NGO professionals were females while seven of them were males. The average age of respondents was thirty-five years old. All respondents were paid staff who had worked with the respective NGOs as the full-time professionals. The 
average period of time for the professionals working with NGOs was 10 years and 3 months. The longest period of time for someone's working with NGOs compared with others, was 26 years. There was also a new comer who had just started to work with one NGO for 6 months.

All respondents were university graduates. Two professionals graduated with master's degrees, while fourteen professionals graduated with bachelor's degrees. They graduated in various fields of study from local universities in Thailand. The study found that the local NGOs in Songkhla province of Thailand had been working for specific issues. The focuses of NGOs' operation included the promotion of quality of work life for workers, the consumer rights protection, the promotion of alternative agriculture, the promotion of the strength of small-scale fishermen network and coastal resources reservation, and the publication of public policy effects. Some comments said:

"This project involves the promotion of health... We support them (workers in the informal sector) to improve their work environment" (Miss A/ NGO1)

“"NGO2' has been operating for the consumers. This NGO emphasizes on the strength of the consumers" (Miss E/ NGO2)

"The alternative agriculture is opposed to chemical agriculture. We promoted the wisdom recovery that could be adopted for community's organization. It should not lead to the commercial purpose. It would lead to the wellbeing and happiness of community" (Mr. H/ NGO3)

"This NGO was involved in helping the small-scale fishermen. We trained the small-scale fishermen. They faced some problems such as boundary problems and trawl problems... This NGO also promoted the marine and coastal resources reservation" (Mr. N/ NGO4)

"This NGO works for the villagers who suffered from public policy" (Miss P/ NGO5)

\subsection{Objective Aspect of Work}

Considering objective aspect of work (i.e. work conditions), this study found that they had flexible working hours. One comment said that "This NGO did not set normal working hours... We could work anytime". Similarly, one professional informed the researcher that the NGO staff had flexible working hours. They did not have to clock in or clock out and they can go out any time (Research Diary, October 5, 2007).

Even though all NGO professionals were paid staff, three NGO professionals stated that they sometimes had worked without salary from their organizations. But they still continued to work for the NGOs. The comments are listed as follows:

"I was acclimatized to this situation. I had been working without compensation for one year" (Miss I/ NGO3)

"I had been working without compensation for a long time... We often worked without salary. I'm okay about this situation” (Mr. J/ NGO3) 
“... (Initially) I didn’t receive any compensation” (Miss P/ NGO5)

However, most professionals seemed to be satisfied with the rates of salary. Thirteen NGO professionals expressed their satisfaction with salary. The rates of salary for the NGO professionals were varied. Some NGO professionals presented that the rates of salary for the NGO professionals were based on the criteria such as individual's capability, work experience, educational level, cost of living, responsibility, and personal satisfaction with salary. In addition to the salary, most NGO professionals had received welfare benefits from NGOs such as medical payment, accident insurance, life insurance, call telephone allowance, and travelling allowance. But welfare benefits for the NGO professionals might be affected by NGOs' budget. When NGOs had not enough budgets, they cannot compensate the professionals.

After the professionals joined NGOs, most of them participated in training courses, seminars, workshops, and study tours, particularly on the topics related to their NGOs' operation. One professional expressed that her skills (such as listening, writing, and speaking) were improved when she attended seminars. Furthermore, the professionals' knowledge, skill, and ability could be developed through their work experiences. When the professionals had more experiences, they could get higher positions (see figure 1). A staff who had more experiences could become a senior staff (i.e. experienced staff). Then later a senior staff would be promoted to a higher position that is a coordinator or director. A coordinator or director refers to a person who works as a manager for the NGO.

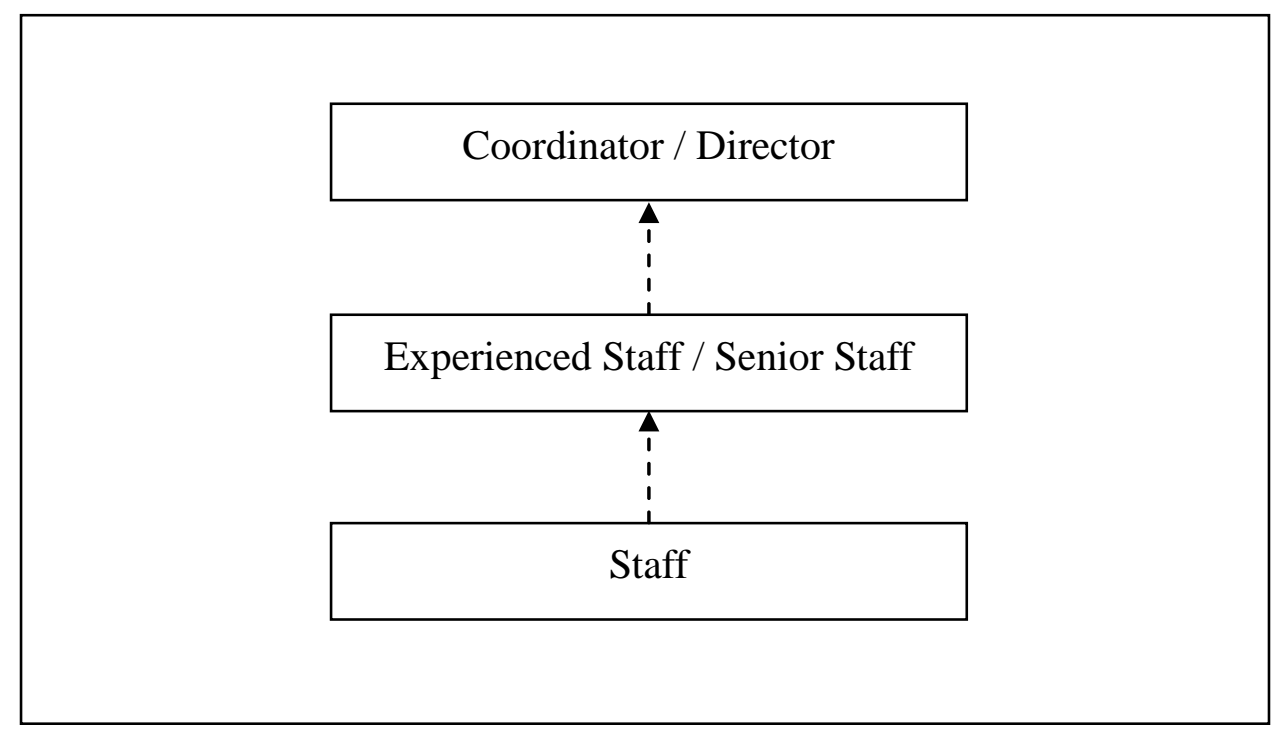

Figure 1. Career Path of the NGO Professionals

According to career path of the NGO professionals, the respondents presented that they have promoted to a higher position but it was not related to career progress or job promotion. They 
argued that after they had experienced many tasks, they became a senior staff who can play more roles but it was not their career growth in NGOs.

\subsection{Subjective Aspect of Work}

The NGO professionals expressed their satisfaction with work as well as their work motivation. They were satisfied when they got a chance to achieve the social goals such as social equality, community development, and people's well-being. Some comments said:

"I like to help people. I can play a part in developing our society in order to achieve social equality... My purpose is to achieve better community development" (Miss B/ NGO1)

“The development of their well-being makes me happy” (Miss D/ NGO1)

"I like social work. I have done something like this. It was more than ideal. Some NGO workers impressed me when they helped me and other people in my village" (Mr. J/ NGO3)

Their comments mentioned above were similar to the notion of task significance that is one of the five core job characteristics developed by Hackman and Oldham (1980). Task significance is defined as the degree to which the job has a significant impact on the lives of other people (Abu Elanain, 2009; Friday \& Friday, 2003; Miller, Mire \& Kim, 2009). Task significance is positively related to employee's satisfaction with work (Abu Elanain, 2009; Friday \& Friday, 2003). Therefore, the professionals who perceived task significance might be satisfied with work.

Additionally, the NGO professionals perceived the NGO work as meaningful. Employees working in NGOs could get a chance to fulfill their lives. Their work motivation was similar to the ideal job characteristics (e.g. serving the country and having an opportunity to help other people) identified by Harzing (2004), for example, 'Miss D' needed to help other people while 'Mr. N' preferred to serve the community. The results of this study are consistent with a study by Gavin and Mason (2004) which contended that individuals need to find fulfillment from their work. One professional said that "I think this job keeps me alive. This job fulfills my life". Based on the professionals' subjective perceptions of work, meaning of work is closely related to meaning of life. While an individual searches for meaningful work, he or she also searches for meaningful life as well (Rosso et al., 2010). A meaningful life is concerned with doing something that he or she believes in (Cartwright \& Holmes, 2006).

\section{Conclusion}

This paper had highlighted the objective and subjective aspects of work in NGOs. The NGO professionals perceived money (i.e. salary) as less important. Although they could promote themselves to a higher position, they did not see it as a career progress. They had given more values on the significance and meaning of work. Since the way that the professionals viewed the significance and meaning of work positively impacts on their performance (Cleavenger \& Munyon, 2013), NGOs could maintain the significance and meaning of NGO work in order to accomplish their organizational goals. A mixed method within qualitative approach and 
Hahn's (2008) data analysis model could be adopted for future qualitative research. The research on work in NGOs should be explored further to gain a better understanding of work in NGOs, particularly the work in NGOs in undiscovered areas. The limitation of the study was that it had only concentrated in Songkhla Province of Thailand. Future studies could expand the area of study to other provinces in Southern Thailand as well as other areas in Thailand. This would broaden the applicability of the findings.

\section{Acknowledgement}

We would like to thank all the participants of the research and all those who provided us the information that we needed.

\section{References}

Abu Elanain, H.M. (2009). Job characteristics, work attitudes and behaviors in a non-western context: Distributive justice as a mediator. Journal of Management Development, 28(5), 457-477.

Ananth, A.P., Prashanthini, V. \& Visvanathan, C. (2010). Healthcare waste management in Asia. Waste Management, 30, 154-161.

Analoui, F. \& Samour, A. (2012). Strategic management: The case of NGOs in Palestine. Management Research Review, 35(6), 473-489.

Baloh, P., Jha, S. \& Awazu, Y. (2008). Building strategic partnerships for managing innovation outsourcing. Strategic Outsourcing: An International Journal, 1(2), 100-121.

Basit, T.N. (2003). Manual or electronic? The role of coding in qualitative data analysis. Educational Research, 45(2), 143-154.

Benz, M. (2005). Not for profit, but for the satisfaction? - Evidence on worker well-being in non-profit firms. KYKLOS, 58(2), 155-176.

Berg, B.L. (2001). Qualitative research methods for the social sciences. (4th ed.). Boston: Allyn and Bacon.

Bhuiyan, S.H. (2010). A crisis in governance: Urban solid waste management in Bangladesh. Habitat International, 34, 125-133.

Bjerneld, M., Lindmark, G., McSpadden, L.A. \& Garrett, M.J. (2006). Motivations, concerns, and expectations of Scandinavian health professionals volunteering for humanitarian assignments. Disaster Management \& Response, 4(2), 49-58.

Brass, J.N. (2012). Why do NGOs go where they go? Evidence from Kenya. World Development, 40(2), 387-401.

Brown, A., Charlwood, A., Forde, C. \& Spencer, D. (2007). Job quality and the economics of new labour: A critical appraisal using subjective survey data. Cambridge Journal of Economics, 31, 941-971.

Brown, L.D., Ebrahim, A. \& Batliwala, S. (2012). Governing international advocacy NGOs. 
World Development, 40(6), 1098-1108.

Bunchapattanasakda, C., Wiriyakosol, S. \& Ya-anan, M. (2012). Leadership roles on employee retaining practice in Nongovernment Organizations (NGOs): The case of Thailand. International Journal of Business and Social Science, 3(8), 199-203.

Burger, R. \& Owens, T. (2010). Promoting transparency in the NGO sector: Examining the availability and reliability of self-reported data. World Development, 38(9), 1263-1277.

Caplow, T. (1964). The sociology of work. New York: McGraw-Hill.

Cartwright, S. \& Holmes, N. (2006). The meaning of work: The challenge of regaining employee engagement and reducing cynicism. Human Resource Management Review, 16, 199-208.

Cleavenger, D.J. \& Munyon, T.P. (2013). It's how you frame it: Transformational leadership and the meaning of work. Business Horizons, 56, 351-360.

Coetzee, M. Bergh, Z.C. (2009). Psychological career resources and subjective work experiences of working adults: An exploratory study. Southern African Business Review, 13(2), 1-31.

Conway, N. \& Briner, R.B. (2002). Full-time versus part-time employees: Understanding the links between work status, the psychological contract, and attitudes. Journal of Vocational Behavior, 61, 279-301.

Das, K. \& Sengupta, S. (2010). Modelling supply chain network: A quality-oriented approach. International Journal of Quality \& Reliability Management, 27(5), 506-526.

Deininger, K. \& Mpuga, P. (2005). Does greater accountability improve the quality of public service delivery? Evidence from Uganda. World Development, 33(1), 171-191.

Desai, V. (2003). Emerging staffing issues in grassroots urban NGOs: The case of Mumbai. Global Built Environment Review, 3(1), 26-36.

Fock, H., Frederick, Y. \& Rodriguez, M. (2010). The effects of sales supervisor relationships on work meaning: The case of Canadian and Chinese salespersons. Industrial Marketing Management, 39, 1069-1077.

Friday, S.S. \& Friday, E. (2003). Racioethnic perceptions of job characteristics and job satisfaction. Journal of Management Development, 22(5), 426-442.

Gavin, J.H. \& Mason, R.O. (2004). The virtuous organization: The value of happiness in the workplace. Organizational Dynamics, 33(4), 379-392.

Gray, R., Bebbington, J. \& Collison, D. (2006). NGOs, civil society and accountability: Making the people accountable to capital. Accounting, Auditing \& Accountability Journal, 19(3), 319-348.

Grint, K. (2005). The sociology of work. (3rd ed.). Cambridge: Polity Press. 
Hackman, J.R. \& Oldham, G.R. (1980). Work redesign. Massachusetts: Addison-Wesley.

Hahn, C. (2008). Doing qualitative research using your computer. London: Sage.

Harsh, M., Mbatia, P. \& Shrum, W. (2010). Accountability and inaction: NGOs and resource lodging in development. Development and Change, 41(2), 253-278.

Harzing, A. (2004). Ideal jobs and international student mobility in the enlarged European Union. European Management Journal, 22(6), 693-703.

Helyer, R. (2011). Aligning higher education with the world of work. Higher Education, Skills and Work-Based Learning, 1(2), 95-105.

Ibrahim, I. \& Aziz, N.A. (2012). The roles of international NGOs in the conservation of bio-diversity of wetlands. Procedia- Social and Behavioral Sciences, 42, 242-247.

Jepson, P. (2005). Governance and accountability of environmental NGOs. Environmental Science \& Policy, 8, 515-524.

Kamery, R.H. (2004). Motivation techniques for positive reinforcement: A review. Proceedings of the Academy of Legal, Ethical and Regulatory Issues, 8(2), 91-96.

Leonard, K.L. (2002). When both states and markets fail: Asymmetric information and the role of NGOs in African health care. International Review of Law and Economics, 22, 61-80.

Ljungberg, J.K. \& Neely, G. (2007). Stress, subjective experience and cognitive performance during exposure to noise and vibration. Journal of Environmental Psychology, 27, 44-54.

Maglio, A.L., Injoque-Ricle, I. \& Leibovich de Figueroa, N. (2010). Work instability: Presentation of an empirical model about its psychological impact. Orientación y Sociedad, 10, 1-20.

Mansfield, C.F., Wosnitza, M. \& Beltman, S. (2012). Goals for teaching: Towards a framework for examining motivation of graduating teachers. Australian Journal of Education \& Development Psychology, 12, 21-34.

Medcof, J.W. \& Rumpel, S. (2007). High technology workers and total rewards. Journal of High Technology Management Research, 18, 59-72.

Mihr, A., Philips, J. \& Duyvesteyn, I. (2011). Human rights NGOs: Imperative or impermissible actors in (post)-conflict societies? International NGO Journal, 6(11), 229-239.

Miles, M.B. \& Huberman, A.M. (1994). Qualitative data analysis. (2nd ed.). Thousand Oaks: SAGE Publications.

Miller, H.A., Mire, S. \& Kim, B. (2009). Predictors of job satisfaction among police officers: Does personality matter? Journal of Criminal Justice, 37, 419-426.

Mitra, A. (2011). Feminist organizing in India: A study of women in NGOs. Women's Studies International Forum, 34, 66-75.

Owczarzak, J. (2010). Activism, NGOs, and HIV prevention in postsocialist Poland: The role 
of "anti-politics". Human Organization, 69(2), 200-211.

Pennerstorfer, A. \& Schneider, U. (2010). What determines the (internal) wage distribution in non-profit organizations? KYKLOS, 63(4), 580-596.

Porter, G. (2004). Work, work ethic, work excess. Journal of Organizational Change Management, 17(5), 424-439.

Rahman, K.M. \& Sultana, M. (2012). Personnel management in NGOs of Bangladesh. Contemporary Management Research, 8(4), 275-296.

Reddick, C.G. \& Turner, M. (2012). Channel choice and public service delivery in Canada: Comparing e-government to traditional service delivery. Government Information Quarterly, $29,1-11$.

Reichel, J. \& Rudnicka, A. (2009). Collaboration of NGOs and business in Poland. Social Enterprise Journal, 5(2), 126-140.

Rosso, B.D., Dekas, K.H. \& Wrzesniewski, A. (2010). On the meaning of work: A theoretical integration and review. Research in Organizational Behavior, 30, 91-127.

Selmer, J. \& Littrell, R. (2010). Business managers' work value changes through down economies. Journal of Chinese Human Resource Management, 1(1), 31-48.

Snir, R. \& Harpaz, I. (2012). Beyond workaholism: Towards a general model of heavy work investment. Human Resource Management Review, 22, 232-243.

Stiles, K. (2002). International support for NGOs in Bangladesh: Some unintended consequences. World Development, 30(5), 835-846.

Tortia, E.C. (2008). Worker well-being and perceived fairness: Survey-based findings from Italy. The Journal of Socio-Economics, 37, 2080-2094.

Vaiman, V., Lemmergaard, J. \& Azevedo, A. (2011). Contingent workers: Needs, personality characteristics, and work motivation. Team Performance Management, 17(5/6), 311-324.

Valentinov, V. (2012). Understanding the rural third sector: Insights from Veblen and Bogdanov. Kybernetes, 41(1/2), 177-188.

Vinopal, J. (2012). The discussion of subjective quality of working life indicators. Sociológia, 44(3), 385-401.

Woodside, M., Melinda, M.G., Devison, J., Hannon, C. \& Sweeney, J.R. (2012). The Qualitative Report 2012, 17(53), 1-16.

\section{Glossary}

Work: a purposeful activity which aims to produce something useful or achieve desired outcomes.

NGO Professional: a person who is a university graduate in any field and who works in Non-Governmental Organization (NGO). 